Article

\title{
Structure-Dependent Effects of Phthalates on Intercellular and Intracellular Communication in Liver Oval Cells
}

\author{
Lucie Čtveráčková ${ }^{1}\left(\mathbb{D}\right.$, Daniel Jančula ${ }^{2}$, Jan Raška ${ }^{1}$, Pavel Babica ${ }^{1,2}$ and Iva Sovadinová ${ }^{1, *(D)}$ \\ 1 RECETOX, Faculty of Science, Masaryk University, Kamenice 753/5, Pavilion A29, \\ 62500 Brno, Czech Republic; lucie.ctverackova@recetox.muni.cz (L.Č.); raska@med.muni.cz (J.R.); \\ pavel.babica@recetox.muni.cz (P.B.) \\ 2 Department of Experimental Phycology and Ecotoxicology, Institute of Botany of the Czech \\ Academy of Sciences, Lidická 25/27, 60200 Brno, Czech Republic; sansan@seznam.cz \\ * Correspondence: iva.sovadinova@recetox.muni.cz; Tel.: +420-549-494-738; Fax: +420-549-492-840
}

Received: 29 July 2020; Accepted: 20 August 2020; Published: 23 August 2020

\begin{abstract}
Humans are exposed to phthalates released from plastics, cosmetics, or food on a daily basis. Phthalates have low acute liver toxicity, but their chronic exposures could induce molecular and cellular effects linked to adverse health outcomes, such as liver tumor promotion or chronic liver diseases. The alternation of gap junctional intercellular communication (GJIC) and MAPK-Erk1/2 pathways in liver progenitor or oval cells can disrupt liver tissue homeostatic mechanisms and affect the development and severity of these adverse outcomes. Our study with 20 different phthalates revealed their structurally dependent effects on liver GJIC and MAPK-Erk1/2 signaling in rat liver WB-F344 cell line with characteristics of liver oval cells. The phthalates with a medium-length side chain (3-6 C) were the most potent dysregulators of GJIC and activators of MAPK-Erk1/2. The effects occurred rapidly, suggesting the activation of non-genomic (non-transcriptional) mechanisms directly by the parental compounds. Short-chain phthalates (1-2 C) did not dysregulate GJIC even after longer exposures and did not activate MAPK-Erk1/2. Longer chain $(\geq 7 \mathrm{C})$ phthalates, such as DEHP or DINP, moderately activated MAPK-Erk1/2, but inhibited GJIC only after prolonged exposures $(>12 \mathrm{~h}$ ), suggesting that GJIC dysregulation occurs via genomic mechanisms, or (bio)transformation. Overall, medium-chain phthalates rapidly affected the key tissue homeostatic mechanisms in the liver oval cell population via non-genomic pathways, which might contribute to the development of chronic liver toxicity and diseases.
\end{abstract}

Keywords: gap junctional intercellular communication; gap junctions; hepatotoxicity; MAP-kinases Erk1/2 activation; non-genomic mechanism; oval cells; phthalates; progenitor cells

\section{Introduction}

Phthalates, i.e., dialkyl- or alkyl/aryl esters of phthalic acid, represent a group of chemicals used in various consumer products such as building materials, clothing, toys, food packaging, cleaning materials, personal care products, cosmetics, nutritional supplements, medical devices, and others [1]. They have been primarily used as plasticizers and are thus present in various plastic materials, such as polyvinylchloride. Phthalates and their metabolites are ubiquitously occurring in the environment, as numerous studies reported their presence in the air, soil, water, and biota, including human body fluids [2-5]. Thus, human beings can be exposed to phthalates throughout their lifetime via ingestion, inhalation, dermal, and also intrauterine exposures [6].

The concerns about the adverse health effects led first to a reduction of the most used phthalate for decades, di-(2-ethylhexyl) phthalate (DEHP), but almost simultaneously to an increase in the use of 
other phthalates [5]. Nowadays, the phthalates which are considered the most toxic, such as DEHP, BBP (benzyl butyl phthalate), DBP (dibutyl phthalate), DOP (dioctyl phthalate), DINP (diisononyl phthalate), and DIDP (diisodecyl phthalate), have also been already regulated for example in the EU, Japan, and the USA [7] (Table S1). Despite these regulations, even in these countries, phthalates are still abundant in products and materials in use, so their environmental occurrence and exposures can be expected for a long time to come $[7,8]$.

The toxicity profiles of phthalates and their potency are determined by their length and branching of dialkyl or alkyl/aryl side chains and physico-chemical properties. In general, phthalates exhibit low acute toxicity in animal models or humans with $L_{50}$ values being between or above $1-30 \mathrm{~g} / \mathrm{kg}$ body weight. In sub-chronic rodent studies, phthalates induced dose-related adverse effects in the liver and kidney, and selected phthalates also affected thyroid and testicular tissue [3,6,9]. After chronic exposure, phthalates are known animal carcinogens, classified endocrine-disrupting chemicals, and inducers of liver injury in laboratory animals $[10,11]$. The human relevance of rodent carcinogenicity of phthalates remains unsettled [9]. For example, DEHP does not exhibit direct genotoxic activity in both rat and human hepatocytes [12]. However, several recent studies suggested links between phthalate exposures and liver inflammation and tumorigenesis in human populations $[13,14]$. A great deal of concern has been raised about their liver toxicity, particularly due to their intensive detoxification in the liver [13]. U.S. EPA has stated the reference dose of DEHP for the risk of increased liver weight as $20 \mu \mathrm{g} / \mathrm{kg}$-day for adolescents and women of reproductive age [15]. Collectively, the liver represents an organ directly affected by phthalate exposures and their adverse health outcomes.

The liver is a complex tissue composed of different cell types, where complex and well organized interactions are essential for liver functions and the maintenance of tissue homeostasis in terms of renewal, regeneration, and repair. Hepatocytes are the main cell type of the liver, constituting $50-80 \%$ of its mass with specialized vital functions such as protein synthesis, detoxification, and the metabolism of lipids and carbohydrates. Not surprisingly, they are the primary target for hepatotoxic compounds. After the disturbance of their number and function, the cells capable of differentiation into hepatocytes are activated (liver homeostatic regulation). They include non-parenchymal adult liver stem cells and bipotential progenitor cells (LSPCs) [16-18], so-called oval cells, and represent the LSPCs invoked during chronic liver injuries [19]. Oval cells possess the characteristics of fetal hepatocytes and biliary cells and can generate hepatocytes and bile duct cells [17]. During the chronic liver injury, the proper function of LSPCs is critical and involves their activation, proliferation, and differentiation to mature hepatocytes and bile duct cells [20]. Thus, the chemically-induced disturbances of LSPC cell regenerative function can disrupt tissue homeostatic mechanisms and contribute to the development and severity of chronic liver toxicities and diseases, including fatty liver diseases, fibrosis, or cirrhosis, and liver cancer [21-27]. LSPCs likely proliferate at the early stages of carcinogenesis and might give rise to hepatocytes becoming tumor progenitors [17].

A key mechanism for the maintenance of liver tissue homeostasis and functions represents an important route for rapid intercellular signaling, called gap junctional intercellular communication (GJIC) [28]. This communication is mediated through gap junctions connecting adjacent cells leading to direct intercellular interactions in the tissue. Gap junctions provide a network for the trafficking of low molecular mass molecules between the neighboring cells. Its dysfunction has been implicated in a variety of toxicologically and pathologically relevant liver processes, such as cell differentiation and death, inflammation. Its dysregulation in the liver is also associated with prevalent adverse outcomes, such as acute or drug-induced liver injury, chronic cholestatic and fatty liver diseases, fibrosis, cirrhosis, as well as portal hypertension [28,29]. Moreover, the dysregulation of GJIC can promote the growth of transformed cells [30-32], and the disruption of liver GJIC and gap junctions is considered to be involved in liver cancer [33-36]. According to the OECD expert group, the inhibition of gap junction communication is regarded as one of the key hallmarks for the identification of non-genotoxic carcinogens [37].

Many liver toxic compounds and environmental contaminants were reported to induce a rapid and often structure-dependent dysregulation of GJIC in vivo or in vitro [38-44]. Thus, the dysregulation of 
GJIC could be the critical cellular process targeted by toxicants via rapid mechanisms independent from genomic signaling, like for example, the activation of various kinases, including mitogen-activated protein kinases MAPK-Erk-1/2 (extracellular signal-regulated kinases 1/2). The MAPK-Erk-1/2 pathway is known to regulate GJIC in different cell types, including liver oval cells [41]. Via the disturbance of liver GJIC, toxicants can cause their disruptive effects on epigenetic regulations, homeostatic processes, and healthy liver functions [35,45]. Previously, there was a structure-dependent relationship of phthalates shown to inhibit intercellular communication in mouse hepatocytes [46].

In this study, we focused on 20 structurally different phthalates representing the most widely used phthalates as well as covering various structural features and molecular weights. Their effects on cell viability, liver GJIC as well as mitogen-activated protein kinases MAPK-Erk1/2 activities in rat liver oval cells WB-F344 were studied. The results presented herein show significant concentrationand time-dependent differences in the ability of structurally different phthalates to rapidly inhibit liver GJIC and activate MAPK-Erk1/2 pathways in liver oval cells. These events might represent critical mechanisms contributing to hazardous liver toxic and hepatocarcinogenic properties of selected phthalates esters.

\section{Results}

\subsection{Phthalates}

Twenty individual phthalates were studied to cover the most used and produced phthalates as well as their different structural features and molecular weights (Table 1 and Figure S1). The selected phthalates include phthalates with mono- as well as di-substituted straight-chain and with short $(\leq 3 \mathrm{C})$, medium (4-6 C), or long carbon chain length ( $\geq 7$ C). Their molecular weight ranges from 180 to 447 and $\log \mathrm{K}_{\mathrm{ow}}$ from $\sim 1$ to 10.36 .

\subsection{Liver GJIC between Oval Cells in Response to Phthalates}

The effects of phthalates on liver oval cells were investigated in immortal rat liver epithelial WB-F344 cells, which exhibit phenotypic characteristics of LSPCs and represent an established in vitro model of oval cells $[27,47]$. None of the tested phthalates disturbed the integrity and confluency of the cell monolayer up to $24 \mathrm{~h}$ exposure to $80 \mu \mathrm{M}$ concentration, as shown for representative phthalates in Figure S2. Studied phthalates induced structure-, concentration- and time-dependent effects on liver GJIC in oval cells (Figures 1 and 2). From these results, the concentrations causing a 50\% decline in GJIC after $0.5 \mathrm{~h}$ exposure $\left(0.5 \mathrm{~h} \mathrm{EC}_{50}\right)$ and the time required for a $50 \%$ decline in GJIC after treatment with $80 \mu \mathrm{M}$ concentration $\left({ }_{80 \mu \mathrm{M}} \mathrm{ET}_{50}\right)$ were calculated (Table 1). Based on their effects on the GJIC, chemical structure, and molecular weight, the studied phthalates can be categorized into six groups-group A-F (Table 1, Figures 1 and 2).

The phthalates from group A (MMP, DMP, DEP, and MBP) are low molecular weight mono- or di-ester phthalates $\left(\mathrm{MW}=180-222 \mathrm{~g} \cdot \mathrm{mol}^{-1}\right.$ ) with short or medium side chains. These phthalates have no or only slight effects on GJIC after 0.5 h exposure to concentrations up to $200 \mu \mathrm{M}\left(0.5 \mathrm{~h} \mathrm{EC}_{50}>200 \mu \mathrm{M}\right.$; Figure 1 (Group A) and Table 1), or even after longer exposures (up to $24 \mathrm{~h}$ ) to the concentration of $80 \mu \mathrm{M}\left(80 \mu \mathrm{M} \mathrm{ET}_{50}>24 \mathrm{~h}\right.$; Figure 2 (Group A) and Table 1).

The phthalates from group B (DPrP, DIPrP, DAP) have a molecular weight from 246 to $250 \mathrm{~g} \cdot \mathrm{mol}^{-1}$ and short $3 \mathrm{C}$ side chains. These phthalates induced the rapid and strong inhibition of cell-cell communication at higher concentrations, with ${ }_{0.5 \mathrm{~h}} \mathrm{EC}_{50}$ values of $70-100 \mu \mathrm{M}$ (Figure 1 (Group B) and Table 1). GJIC-dysregulating effects caused by the concentration of $80 \mu \mathrm{M}$ did not become more apparent with increasing exposure time $\left(80 \mu \mathrm{MET} \mathrm{T}_{50}>24 \mathrm{~h}\right.$; Figure 2 (Group B) and Table 1).

Group C (DBP, DIBP, BBP, DPeP, DCHP, DPhP) represents phthalates with a molecular weight of 278-330 $\mathrm{g} \cdot \mathrm{mol}^{-1}$ and a medium-sized side chain (4-6 C). Phthalates from this group dysregulated GJIC in WB-F344 cells with the highest potencies, with the ${ }_{0.5 \mathrm{~h}} \mathrm{EC}_{50}$ values of $13-39 \mu \mathrm{M}$ (Figure 1 (Group C) and Table 1). At $80 \mu \mathrm{M}$ concentration, these phthalates rapidly induced the complete inhibition of GJIC 
within the first $10 \mathrm{~min}\left(80 \mu \mathrm{M} \mathrm{ET}_{50}<10 \mathrm{~min}\right.$; Figure 2 (Group C) and Table 1). GJIC did not recover during the extended exposure times (up to $24 \mathrm{~h}$ ), except for DPhP, which had a transient inhibitory effect on GJIC. After $80 \mu \mathrm{M}$ treatment with DPhP, GJIC was inhibited entirely during the initial $10 \mathrm{~min}$, but then gradually recovered even in the continuous presence of the chemical in the medium, restoring to $50 \%$ of the control after $5.5 \mathrm{~h}$ of exposure and entirely after $24 \mathrm{~h}$.

The phthalates from group D (DHpP, DIHpP) have a higher molecular weight of $363 \mathrm{~g} \cdot \mathrm{mol}^{-1}$ and bear a longer $7 \mathrm{C}$-side chain. These phthalates had a medium effect on liver GJIC between oval cells with a $0.5 \mathrm{~h} \mathrm{EC}_{50}$ value of $\sim 50 \mu \mathrm{M}$ (Figure 1 (Group D) and Table 1) with a relatively rapid response $\left(80 \mu \mathrm{M} \mathrm{ET}_{50} \sim 20 \mathrm{~min}\right.$; Figure 2 (Group D) and Table 1).

DEHP, DOP, and DINP, which were categorized into group E, have a molecular weight of 391-419 $\mathrm{g} \cdot \mathrm{mol}^{-1}$ and long side chains (7-9 C). They caused only a weak GJIC inhibition after $0.5 \mathrm{~h}$ exposure (down to $60-80 \%$ of the control) with ${ }_{0.5 \mathrm{~h}} \mathrm{EC}_{50}>200 \mu \mathrm{M}$ (Figure 1 (Group E) and Table 1). With increasing exposure time, their effects on GJIC became more pronounced, with the ${ }_{80 \mu \mathrm{M}} \mathrm{ET}_{50}$ values ranging between 3.5 and $12 \mathrm{~h}$, and the nearly complete inhibition of GJIC was observed after $24 \mathrm{~h}$ (Figure 2 (Group E) and Table 1).

Finally, the phthalates with the highest molecular weight of $447 \mathrm{~g} \cdot \mathrm{mol}^{-1}$ (DDP, DIDP) and the longest chain length (C10) belong to group F. These phthalates had effects similar to group A, i.e., no or only slight effects on liver GJIC with $0.5 \mathrm{~h} \mathrm{EC}_{50}>200 \mu \mathrm{M}$ (Figure 1 (Group F) and Table 1) not increasing with exposure time $\left(80 \mu \mathrm{M} \mathrm{ET}_{50}>24 \mathrm{~h}\right.$; Figure 2 (Group F) and Table 1).

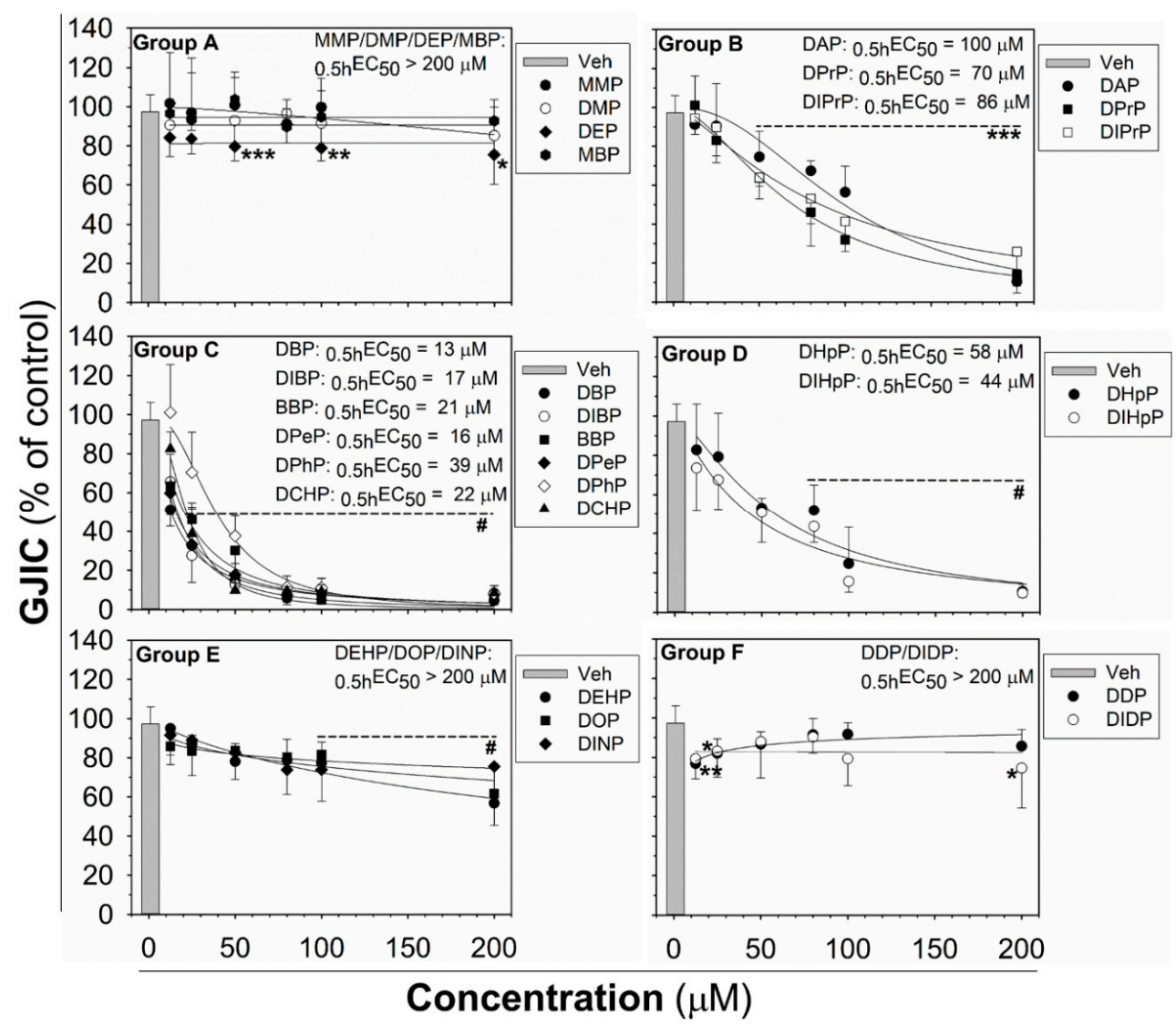

Figure 1. Concentration-dependent effects of phthalates on liver gap junctional intercellular communication (GJIC) in rat oval WB-F344 cells after $0.5 \mathrm{~h}$ treatment. The studied phthalates were distinguished into six groups (group A-F) based on their biological activities, structures, and physico-chemical properties. Data represent the means (SD) of independent experiments $(n>3)$. Significant differences from the vehicle control were determined by one-way ANOVA $\left({ }^{*}, p \leq 0.050\right.$; $\left.* *, p \leq 0.01 ;{ }^{* * *}, p \leq 0.001\right)$ or Kruskal-Wallis ANOVA $(\#, p \leq 0.05)$. 
Table 1. Overview of the studied phthalates and their structures, physico-chemical properties, and biological activities, based on which they were distinguished into six groups-group A-F. The color scale is green to yellow to red with higher effects getting the green color and low or no effects getting the red color.

\begin{tabular}{|c|c|c|c|c|c|c|c|}
\hline \multirow{2}{*}{ Phthalate } & \multirow{2}{*}{$\begin{array}{l}\text { Carbon Chain } \\
\text { Length }\end{array}$} & \multirow{2}{*}{$\mathrm{MW}^{\mathrm{a}} \mathrm{g} / \mathrm{mol}$} & \multirow{2}{*}{$\log _{\text {Kow }}{ }^{a}$} & \multirow{2}{*}{ Group } & \multicolumn{2}{|c|}{ GJIC } & \multirow{2}{*}{$\begin{array}{c}\begin{array}{c}\text { MAPK-Erk1/2 } \\
\text { Activation }\end{array} \\
\text { FOC }^{\mathrm{d}}(0.5 \mathrm{~h})\end{array}$} \\
\hline & & & & & $0.5 \mathrm{~h} \mathrm{EC}_{50} \mathrm{~b}(\mu \mathrm{M})$ & $80 \mu \mathrm{M} E T_{50}^{c}(\mathrm{~min})$ & \\
\hline MMP Monomethyl phthalate & Short & 180 & $9 \times 10^{-1}$ to 1.50 & $\mathrm{~A}$ & $>200$ & $>1440$ & 0 \\
\hline DMP Dimethyl phthalate & Short & 194 & 1.46 to 1.90 & $\mathrm{~A}$ & $>200$ & $>1440$ & 0 \\
\hline DEP Diethyl phthalate & Short & 222 & 2.21 to 3 & A & $>200$ & $>1440$ & 0 \\
\hline MBP Monobutyl phthalate & Medium & 222 & 2.37 to 3.07 & A & $>200$ & $>1440$ & 0 \\
\hline DPrP Dipropyl phthalate & Short & 250 & 3.14 to 3.87 & $\mathrm{~B}$ & 70 & $>1440$ & 5 \\
\hline DIPrP Diisopropyl phthalate & Short & 250 & 2.61 to 3.48 & $\mathrm{~B}$ & 86 & $>1440$ & 8 \\
\hline DAP Diallyl phthalate & Short & 246 & 2.92 to 3.36 & B & 100 & $>1440$ & 5 \\
\hline DBP Dibutyl phthalate & Medium & 278 & 4.39 to 4.83 & $\mathrm{C}$ & 13 & 2 & 24 \\
\hline DIBP Diisibutyl phthalate & Medium & 278 & 3.81 to 4.46 & $\mathrm{C}$ & 17 & 10 & 32 \\
\hline BBP Benzyl butyl phthalate & Medium & 312 & 3.57 to 4.91 & C & 21 & 2 & 21 \\
\hline DPeP Dipentyl phthalate & Medium & 306 & 5.19 to 5.89 & C & 16 & 10 & 32 \\
\hline DCHP Dicyclohexyl phthalate & Medium & 330 & 4.79 to 6.20 & $\mathrm{C}$ & 22 & 10 & 28 \\
\hline DPhP Diphenyl phthalate & Medium & 318 & 2.82 to 4.61 & C & 39 & 10 & 7 \\
\hline DHpP Diheptyl phthalate & Long & 363 & $5.65-6.82$ & $\mathrm{D}$ & 58 & 25 & 4 \\
\hline DIHpP Diisoheptyl phthalate & Long & 363 & 7.4 & $\mathrm{D}$ & 44 & 17 & 4 \\
\hline DEHP Di-(2-ethylhexyl) phthalate & Long & 391 & $5.11-8.35$ & $\mathrm{E}$ & $>200$ & 207 & 3 \\
\hline DOP Dioctyl phthalate & Long & 391 & 7.84 to 9.08 & $\mathrm{E}$ & $>200$ & 292 & 3 \\
\hline DINP Diisononyl phthalate & Long & 419 & 8.57 to 11.2 & $\mathrm{E}$ & $>200$ & 711 & 5 \\
\hline DDP Didecyl phthalate & Long & 447 & 9.05 & $\mathrm{~F}$ & $>200$ & $>1440$ & 4 \\
\hline DIDP Diisodecyl phthalate & Long & 447 & 10.36 & $\mathrm{~F}$ & $>200$ & $>1440$ & 4 \\
\hline
\end{tabular}

${ }^{a}$ The iCSS ToxCast Dashboard (accessed on 20 May 2019), National Center for Biotechnology Information, PubChem Database (accessed on 20 May 2019), MW—molecular weight, log

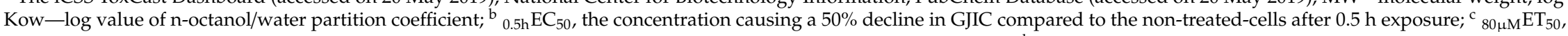
the time causing a $50 \%$ decline in GJIC compared to the non-treated-cells after treatment to the concentration of $80 \mu \mathrm{M}$; ${ }^{\mathrm{d}}$ FOC, the fraction of the control (non-treated cells). 


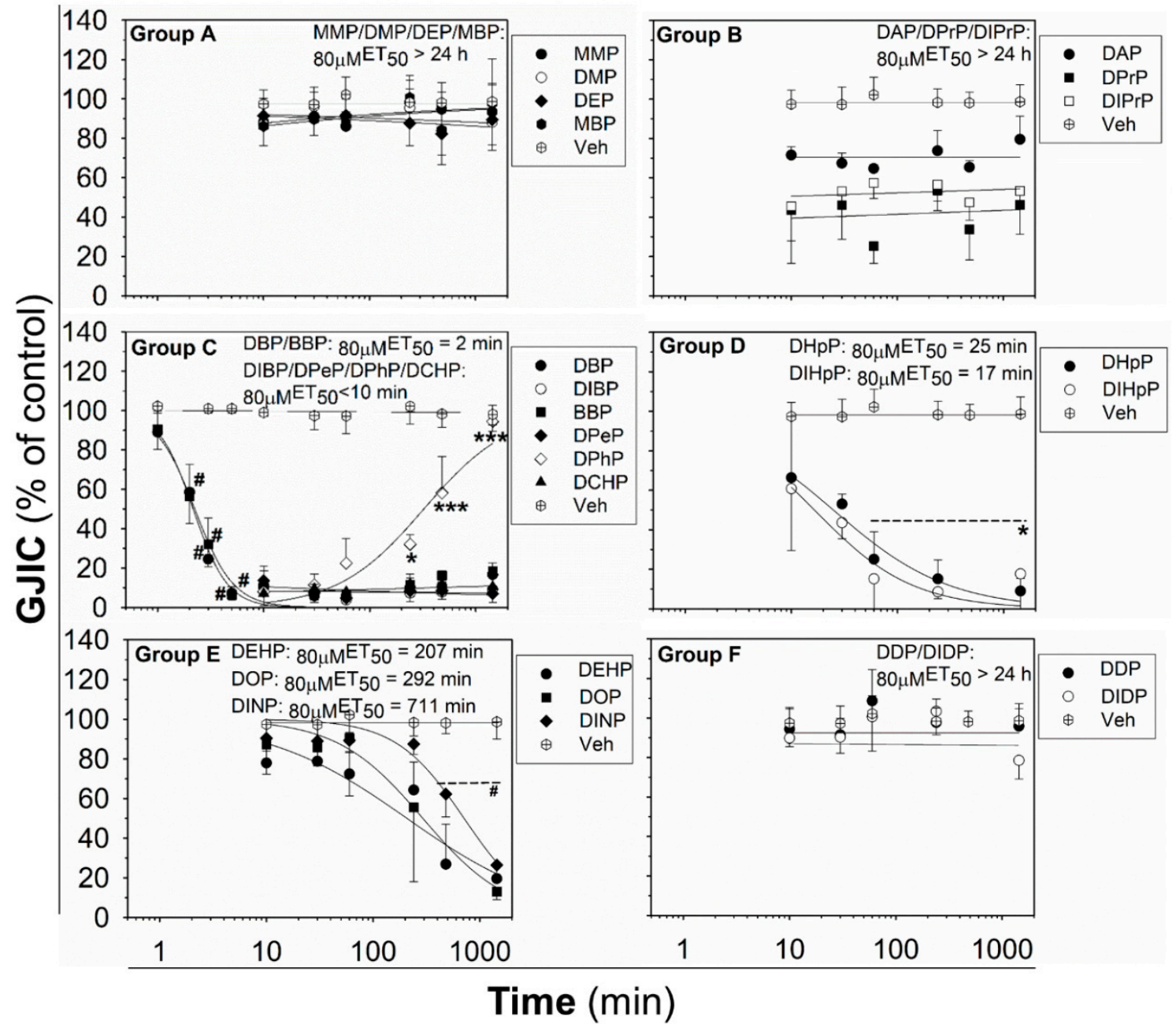

Figure 2. Time-dependent effects of phthalates on liver GJIC in rat oval WB-F344 cells after treatment with a concentration of $80 \mu \mathrm{M}$ up to $24 \mathrm{~h}$ (1440 $\mathrm{min})$. Data represent the means (SD) of independent experiments $(n>3)$. Time points: 1, 2, 3, 5, 10, 30 (0.5 h), 60 (1 h), $240(4 \mathrm{~h}), 480(8 \mathrm{~h})$, and $1440(24 \mathrm{~h})$ min. The studied phthalates were distinguished into six groups (group A-F) based on their biological activities, structures, and physico-chemical properties. Significant differences from the effect evaluated after the first exposure time (1 min for DBP, DIB; $10 \mathrm{~min}$ for all other phthalates) were determined by one-way ANOVA followed by Dunnett's test $\left({ }^{*}, p \leq 0.050 ;{ }^{* * *}, p \leq 0.001\right)$ or Kruskal-Wallis ANOVA followed by Dunn's test (\#, $p \leq 0.050)$.

\subsection{Viability of Liver Oval Cells in Response to Phthalates}

The cytotoxicity testing was done for each phthalate to establish the highest non-cytotoxic concentration after $24 \mathrm{~h}$ exposure, to be sure that the observed GJIC inhibition was not due to cytotoxicity and decreased cell density by necrotic or apoptotic cell death, or inhibited proliferation. After $24 \mathrm{~h}$ exposure, the cytotoxicity of phthalates $(10-200 \mu \mathrm{M})$ was assessed by the simultaneous evaluation of three vital cellular processes: cell respiration and dehydrogenase activity by Alamar Blue $^{\circledR}$ reduction, esterase activity and membrane integrity by CFDA-AM (5-carboxyfluorescein diacetate-acetoxymethyl ester) cleavage and retention, and lysosomal membrane integrity and energetic imbalance by neutral red uptake (NRU). None of the phthalates induced lethal cytotoxicity or a reduction of cell viability, according to Alamar Blue ${ }^{\circledR}$ assay (Figure S3). Similarly, no significant effects on NRU were observed, except for DCHP, causing a partial reduction of dye uptake (by an app. 50\%) at the highest experimental concentration (Figure S4). CFDA-AM cleavage was the most sensitive parameter (Figure 3), which was partially, but significantly reduced (by app. 30-50\%) by DAP, BBP, DCHP, 
$\mathrm{DPhP}$, and $\mathrm{DHpP}$ at $200 \mu \mathrm{M}$ concentration, i.e., the concentration two- to ten-times higher than their $0.5 \mathrm{~h} \mathrm{EC}_{50}$ values for GJIC inhibition. DPhP caused no concentration-dependent effect on cell viability in the CFDA-AM assay, since it reduced cell viability at the same extent (app. 30\% decrease) at the concentrations of 10 and $50 \mu \mathrm{M}$, but not at the concentration of $100 \mu \mathrm{M}(90 \%$ of non-treated control).

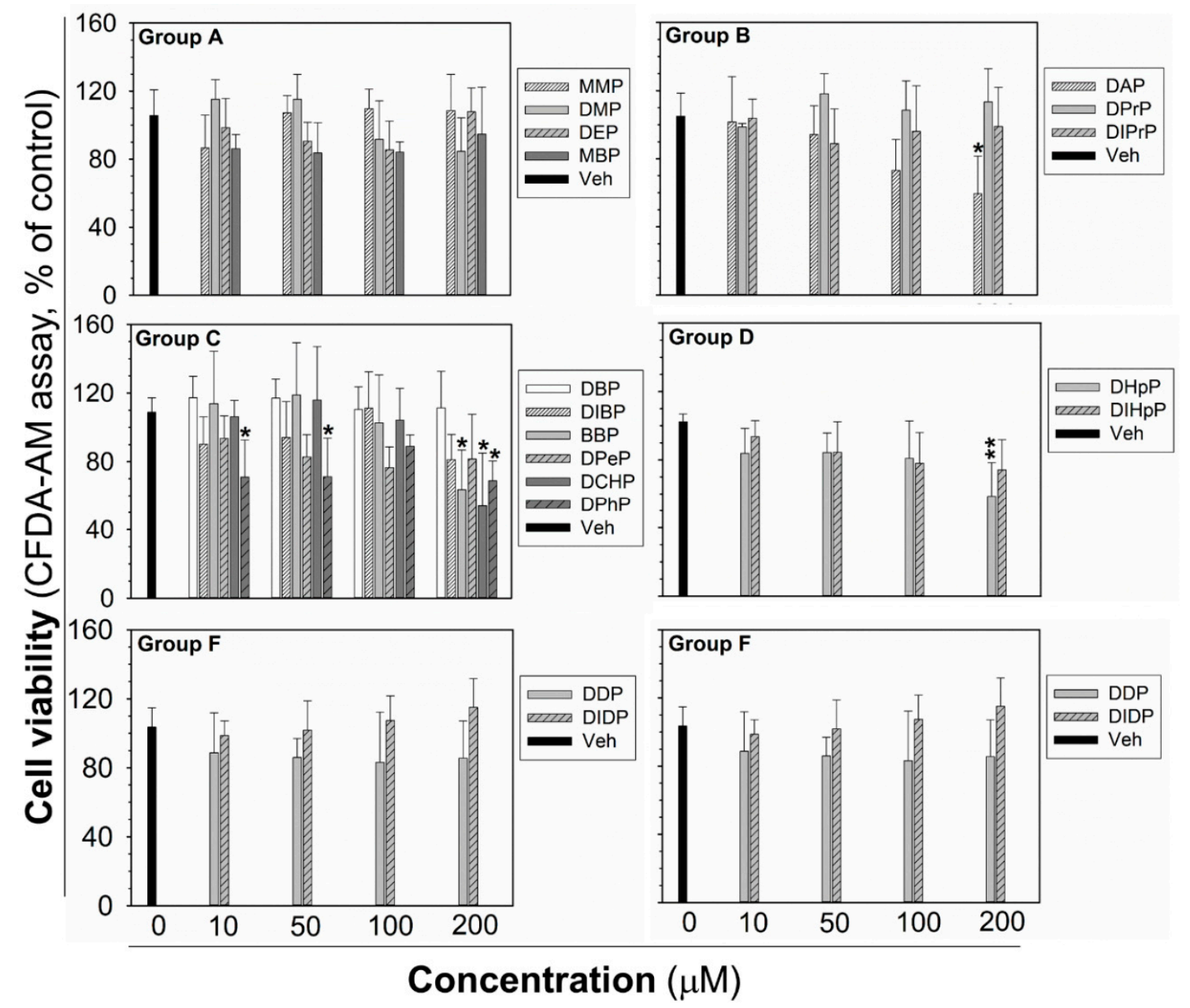

Figure 3. Cell viability of rat liver oval WB-F344 cells after $24 \mathrm{~h}$ treatment with phthalates evaluated by CFDA-AM assay. The studied phthalates were distinguished into six groups (group A-F) based on their biological activities, structures, and physico-chemical properties. Data represent the means (SD) of independent experiments $(n>3)$. Significant differences from the vehicle control were determined by one-way ANOVA followed by Dunnett's test $\left({ }^{*}, p \leq 0.050 ;{ }^{* *}, p \leq 0.01\right)$. CFDA-AM-5-carboxyfluorescein diacetate-acetoxymethyl ester.

In addition, the eventual effects of phthalates on cell density, attachment, and confluency of the monolayer were observed by brightfield microscopy in each SL/DT (scalpel loading/dye transfer) experiment. None of the tested phthalates disturbed integrity and $100 \%$ confluency of the cell monolayer up to $24 \mathrm{~h}$ exposure to $80 \mu \mathrm{M}$ concentration, as shown for the representative phthalates (Figure S2). Moreover, the intact plasma membrane of healthy cells has low permeability for lucifer yellow. In contrast, the occurrence of damaged and necrotic cells in the SL/DT assay leads to more intense lucifer yellow staining in the background, i.e., outside the cut and dye-transfer area [48], as demonstrated for a cytotoxic treatment of WB-F344 cells with $100 \mu \mathrm{M}$ triclosan (Figure S5). No such signs of cell damage or cytotoxicity were observed for any of the tested phthalates up to $24 \mathrm{~h}$ exposure to $80 \mu \mathrm{M}$, including the phthalates that were found to reduce cell viability at higher concentrations by more than 25\% (25-50\%; DAP, DIBP, BBP, DPeP, DCHP, DPhP, DHpP, DIHpP) in at least one of the cell viability assays (representative images shown in Figure S5). 


\subsection{MAPK-Erk1/2 Pathway in Liver Oval Cells in Response to Phthalates}

Since MAPKs and their pathways are crucial for healthy liver function [49] and implicated in the control of GJIC [45], the changes in the activity of MAPK-Erk1/2 were investigated in response to phthalates in rat liver oval WB-F344 cells. After $0.5 \mathrm{~h}$ exposure of WB-F344 cells to $10 \mathrm{nM}$ TPA (12-O-tetradecanoylphorbol 13-acetate), which was used as a positive control and known GJIC inhibitor and tumor promoter, rapidly and significantly increased ( $\sim 30$-fold increase) the levels of phosphorylated, i.e., activated, MAPK-Erk1 and 2 (Figure 4; original, uncropped and unadjusted images in Figures S6-S9). The phthalates from group A did not induce any detectable phosphorylation of MAPK-Erk1/2. All the phthalates from the other groups activated the MAPK-Erk1/2 pathways with different potencies (Figure 4 and Table 1). The phthalates from groups D-F were weak activators and induced MAPK-Erk1/2 phosphorylation to levels 3-5-fold above the control. The phthalates from group B were medium activators of MAPK-Erk1/2 with 5-8-fold higher levels of phosphorylation than in the vehicle-treated cells. The most potent activators were shown to be the phthalates from group C, which increased levels of phosphorylated MAPK-Erk1/2 to 7-32-fold of that of the control.

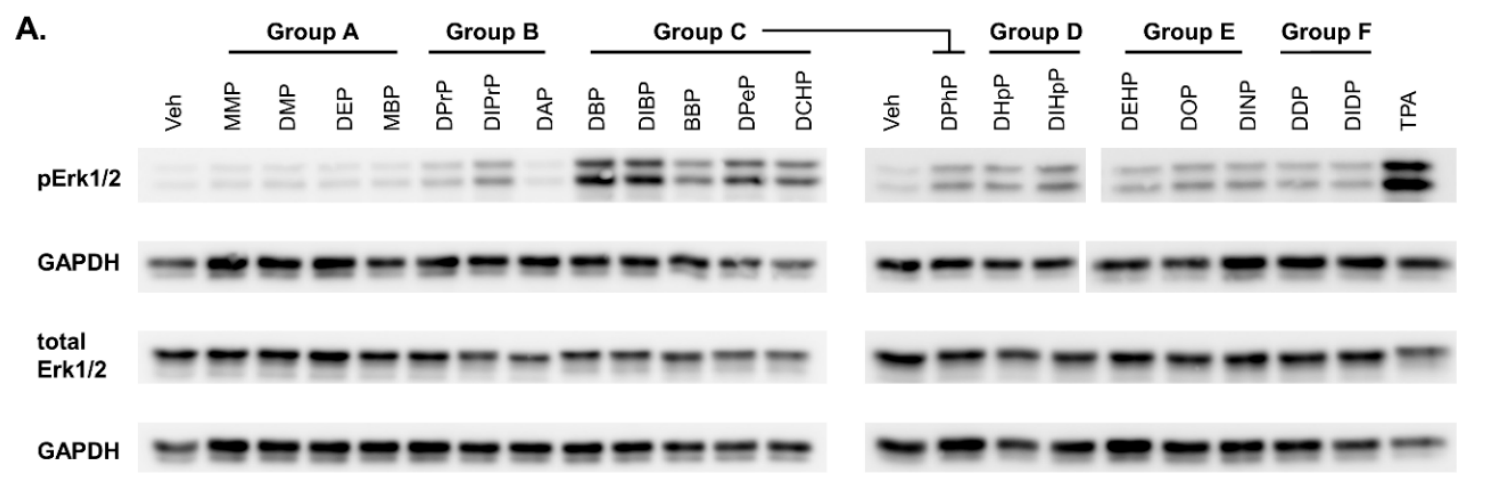

B.

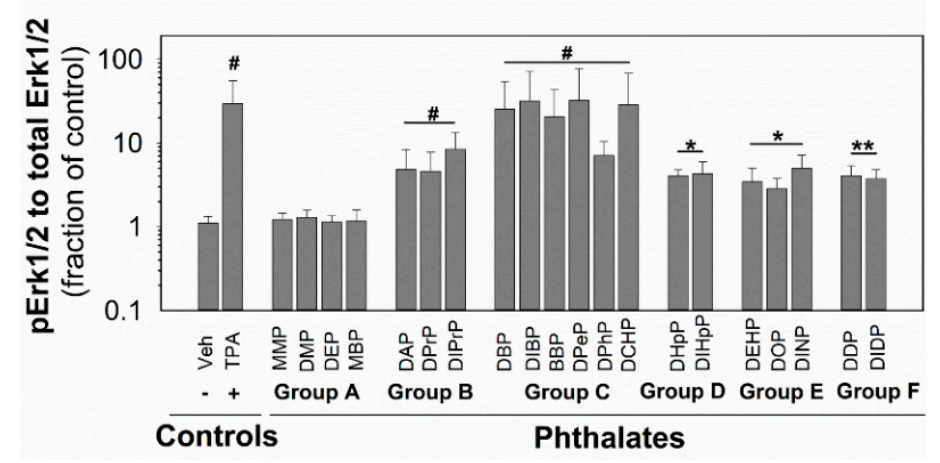

Figure 4. Activation of MAPK-Erk1/2 pathway in rat liver oval WB F-344 cells in response to $0.5 \mathrm{~h}$ treatment with phthalates $(80 \mu \mathrm{M})$. (A) A representative immunoblot for phosphorylated Erk1/2 (pErk1/2), total Erk1/2, and GAPDH (glyceraldehyde-3-phosphate dehydrogenase). The studied phthalates were distinguished into six groups (group A-F) based on their biological activities, structures, and physico-chemical properties. The positive control was treated with $10 \mathrm{nM}$ TPA (12-O-tetradecanoylphorbol 13-acetate). (B) Densitometric analysis of pErk1/2 normalized to total Erk1/2 represented as the fraction of the control. Data are presented as the means (SD) of independent experiments $(n>3)$, significant differences from the vehicle control were determined by two-tailed $t$-test $\left({ }^{*}, p \leq 0.050 ;{ }^{* *}, p \leq 0.010\right)$ or Mann-Whitney U test $(\#, p \leq 0.05)$.

\subsection{Expression of Peroxisome Proliferator-Activated Receptors (Ppar) in Rat Liver Oval Cells WB-F344}

The hepatotoxic effect of phthalates via Ppar $\alpha$ signaling networks have been observed in rodents, but not in humans [50,51]. To find out if the observed effects caused by phthalates on liver GJIC or MAPK-Erk 1/2 signaling pathways in oval cells in this study might be connected with Ppars, 
we evaluated the expression of Ppar isoforms in WB-F344 cells. The WB-F344 cells under the conditions used in this study did not express Ppar $\alpha$ and Ppar $\gamma$, while Ppar $\beta / \delta$ was expressed only at a low level, as measured by RT-PCR (Figure 5; original, uncropped and unadjusted images in Figures S10 and S11). Therefore, the effects of phthalates on the model of WB-F344 cells and Ppar signaling networks are not likely to be related.

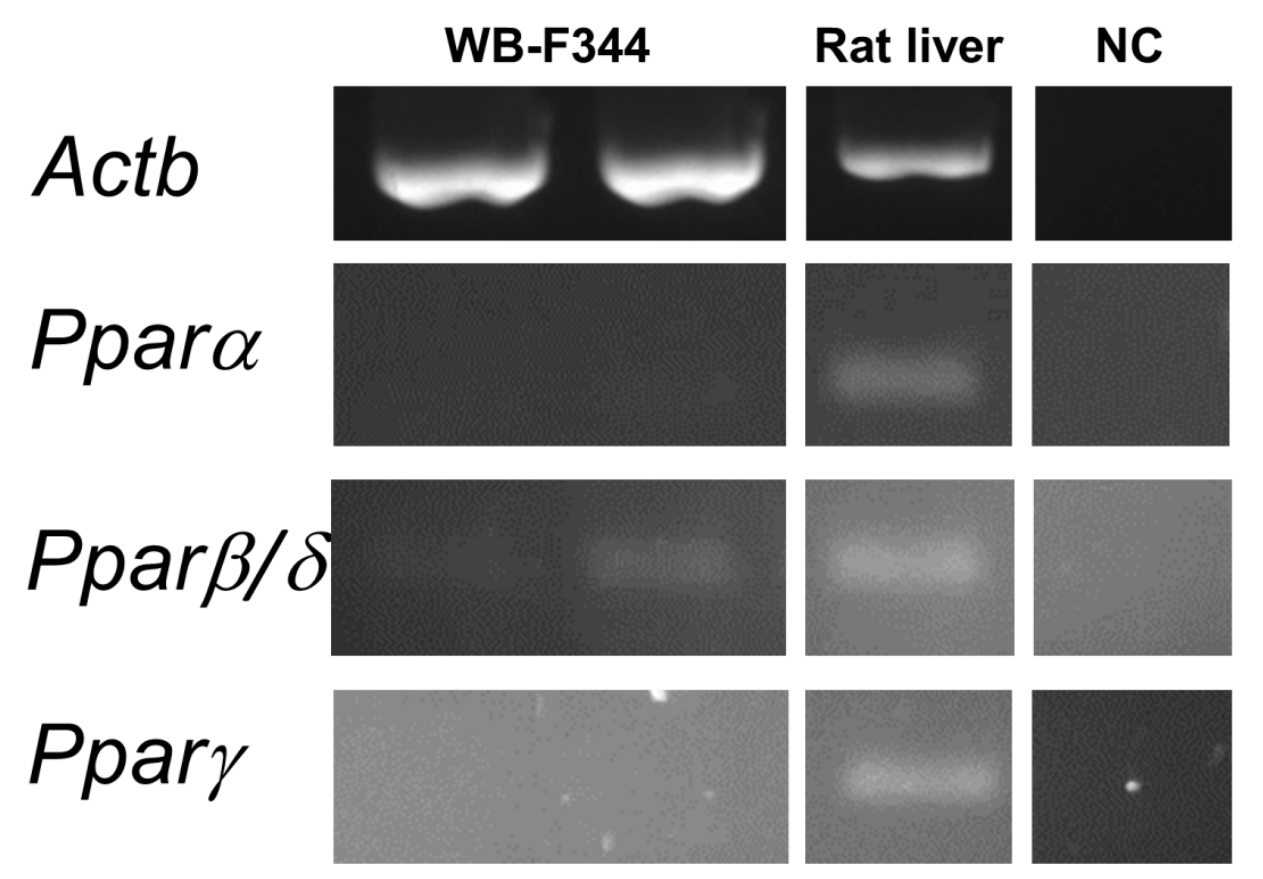

Figure 5. Expression of the Ppar isoforms in rat liver oval WB-F344 cells. RNA was isolated independently from two different cultures of WB-F344. Expression of $\operatorname{Ppar} \alpha, \beta / \delta$, and $\gamma$ was determined by RT-PCR. The reference gene $\beta$-actin $(A c t b)$ was used as a loading control. A sample of RNA extracted from rat liver tissue was used as a positive control to confirm the successful amplification of all Ppar isoforms by RT-PCR. Negative control (NC) sample was negative for all isoforms.

\section{Discussion}

Even though phthalates are nowadays regulated in some countries, hundreds of tons are still produced all around the world, and products containing phthalates are still broadly used, leading to ongoing everyday life human exposures. Animal studies suggested that some phthalates cause hepatotoxicity, developmental, and reproductive toxicity [52] (Table S2). Human phthalate exposures were associated with the increased risks of metabolic disorders, including obesity, diabetes, insulin resistance, and deteriorated liver function [53-55]. Chronic exposures can lead to the continuous accumulation and intensive detoxification of phthalates in the liver [56]. Thus, liver cells are likely to be exposed to the highest concentration of phthalates in the body [57], and it is crucial to understand the liver toxicity of phthalates.

In our study, the phthalates were discovered as potent dysregulators of GJIC and activators of the MAPK-Erk1/2 pathways in liver oval cells, and these effects were structure-dependent. Because of their critical role in supporting liver homeostasis, liver gap junctions and GJIC are known to be affected in chronic liver diseases and toxicities [34,58]. However, information on the effect of phthalates on liver GJIC is relatively scarce, and the data are mostly from tests in vivo or with hepatocytes (Table S2). Previous studies found that DEHP and DINP inhibited GJIC in vivo in the liver of mice and rats, but not in the liver of hamsters or monkeys [59-61]. These in vivo effects were primarily attributed to major biotransformation products of DEHP and DINP, namely mono(2-ethyl hexyl)phthalate (MEHP) and mono(isononyl)phthalate (MINP). These metabolites and other phthalate monoesters with longer $(>7 \mathrm{C})$ or branched side chains also inhibited GJIC in vitro in primary mouse or rat hepatocytes. 
However, they did not affect GJIC in the hamster, monkey, or human hepatocytes after 4-24 h exposures to $200-500 \mu \mathrm{M}$. This species-specific pattern was attributed to intraspecific differences in the effects of phthalate monoesters on peroxisomal proliferation (thus on the activation of Ppar $\alpha$ and its signaling networks). The human relevance of rodent data on phthalate-induced tumor promotion, peroxisome proliferation, and GJIC inhibition is questionable $[50,62,63]$.

In comparison with the earlier data reported for longer/branched monoesters in primary mouse or rat hepatocytes, we observed qualitatively and quantitatively different responses in rat liver oval cells to phthalic acid diesters. Most notably, the phthalates with medium-length (4-6 C) carbon side chains such as DBP, DIBP, BBP, DPeP, DCHP, and DPhP (i.e., Group C) were the most active and rapid GJIC inhibitors with effective ${ }_{0.5 \mathrm{~h}} \mathrm{EC}_{50}$ values of $13-39 \mu \mathrm{M}(4-12 \mathrm{mg} / \mathrm{L})$, as well as the most potent MAPK-Erk1/2 activators. The effective concentrations and times required for GJIC inhibition by these phthalate diesters were lower than those previously reported for longer/branched-chain monoesters in primary mouse and rat hepatocytes, where concentrations $>50-100 \mu \mathrm{M}$ were usually required to induce $\geq 50 \%$ inhibition of GJIC after $4-24 \mathrm{~h}$ of exposure [46,64]. According to these earlier studies in rodent hepatocytes (other types of liver cells were not assessed regarding the possible liver toxicity of phthalates), phthalate monoesters with shorter straight chains did not inhibit liver GJIC [46]. In contrast, monoesters with longer/branched-chains inhibited GJIC with a relatively uniform concentration- and time-response pattern [64].

Here, we were able to separate the tested phthalates into six different groups with a distinct profile of liver GJIC inhibition and MAPK-Erk1/2 activations. Short-chain diesters and monoesters (Group A) neither inhibited GJIC nor activated MAPK-Erk1/2. Phthalate diesters with 3 C (Group B) or 7 C (Group D) side chains were also rapid GJIC inhibitors and MAPK-Erk1/2 activators. However, still less potent than Group C. Interestingly, the effects of Group B phthalates (DPrP, DIPrP, DAP) did not become more pronounced with increasing exposure time, as observed for Group D (DHpP, DIHpP). The phthalates from group E (DEHP, DOP, DINP) rapidly activated MAPK-Erk1/2 but caused only a weak inhibition of GJIC even at concentrations $\sim 200 \mu \mathrm{M}$. Nevertheless, their GJIC inhibiting effects progressed with longer exposure times ( ${ }_{80 \mu \mathrm{M}} \mathrm{ET}_{50}$ values of 3.5 to $12 \mathrm{~h}$ ). Finally, long-side chain phthalate diesters (Group F-DIDP, DDP) did not induce major effects on GJIC like Group A. However, in contrast to Group A, they rapidly activated MAPK-Erk1/2 with a potency comparable to Group B, D or E. The alterations of GJIC by Groups B-D and the activation of MAPK-Erk1/2 by Groups B-F were observed within several minutes of exposure, indicating they were most likely caused directly by the parental phthalate diester compounds, not by monoesters produced by eventual phthalate (bio)transformation.

We were able to observe relatively more nuanced structure-dependent effects of phthalate diesters in our study than in the previous studies of GJIC in primary hepatocytes exposed to phthalate monoesters. Importantly, similar structure-dependent activity has been observed in the studies reporting adverse developmental effects after treatment with phthalates. Short phthalates (methyl and ethyl) exhibit low or no rodent developmental toxicity, while medium-size phthalates (butyl) increased developmental malformations [51,52]. In agreement with this structure-dependent activity, the phthalates with medium carbon side chains were also found to be the most active in ToxCast assays with the percentage of "active" assays ranging from $7.33 \%$ to $26.97 \%$ (Table S2). These phthalates were also the most active in ToxCast assay endpoints in each gene set concerning hepatotoxicity or hepatic tumors and in the hepatotoxicity assays conducting not only with rat hepatocytes but also with human hepatocytes or human liver HepG2 cells [65].

For phthalates with medium- or long-side chain length, the transcriptional activation of Ppar $\alpha$, and subsequent downstream events such as peroxisome proliferation, represent essential mechanisms of toxicity in rodents $[50,51]$. This finding was confirmed for active phthalates from this study in appropriate ToxCast assays (Table S2). Peroxisomal proliferation is a species-specific process where humans are considered to be a largely non-responsive species to this mechanism of action $[57,66]$, due to qualitative differences in the transcriptional networks controlled by Ppar $\alpha$ activation [50]. 
However, it has also been shown that PPAR $\alpha$ activation and peroxisomal proliferation are not essential for liver tumorigenesis induced by phthalates in humans $[10,67]$. Combined data from animal models and exposed humans suggest that multiple molecular signals and pathways activated in several cell types in the liver, rather than a single molecular event in hepatocytes, contribute to the carcinogenic effects of DEHP [68].

Our results support that the Ppar $\alpha$-independent events induced in the critical population of liver oval cells might participate in liver toxicity and liver tumorigenesis caused by phthalates because Ppar $\alpha$ was not found to be significantly expressed in WB-F344 cells. The inhibition of GJIC and the activation of MAPK in these liver oval cells by active phthalates were therefore elicited by another, PPAR $\alpha$ - and peroxisome proliferation-independent mechanism. Moreover, the timing of oval cell responses to Group B-D phthalates ( $\leq 30 \mathrm{~min}$ ) further suggest that these effects were not mediated via the transactivation of nuclear receptors, such as Ppar $\alpha$, and subsequent gene expression changes (i.e., genomic mode of action), but rather through rapid alterations of signal transduction pathways controlling the gating of gap junction channels or the activation of MAPKs (i.e., non-genomic mechanisms). However, genomic mechanisms, other than the Ppar signaling pathway, possibly in combination with phthalate transformation to monoesters, could be involved in the delayed inhibition of GJIC induced by Group E or in the later phases of sustained GJIC inhibition caused by Groups C or D.

Phosphorylated MAPK-Erk 1/2 (pErk1/2) is the activated form of MAPK-Erk, and the key component of the Ras/Raf/Mek/Erk pathway, whose balanced liver activity is crucial for healthy liver function [49]. The role of MAPK-Erk1/in hepatic metabolism and its increase in states of obesity have also been discussed [49]. Phosphorylated MAPK-Erk1/2 activates a variety of target molecules involved in the regulation of cell cycle progression, proliferation, apoptosis, and migration of liver cells, and also other processes crucial to promote the development of liver cancer, such as invasion and metastasis [69]. In our study, all phthalates except Group A rapidly activated the MAPK-Erk1/2 pathways in WB F-344 cells. Similar to a known tumor promotor, TPA, MAPK-Erk1/2 activation was associated with the rapid (Groups B-D) or delayed (Group E) inhibition of GJIC. Thus, this rapid MAPK-Erk 1/2 activation in liver oval cells after phthalate treatment might lead to an imbalance of hepatic tissue homeostasis and other liver functions, as well as might contribute to tumor-promoting and progressing stages of hepatocellular carcinoma. The activation of liver oval cells has been associated with liver tissue damage, inflammation, fatty liver disease, and these cells were found to play a crucial role in the progression of hepatocellular carcinoma [26]. Correspondingly, BBP, inhibiting GJIC and activating MAPK-Erk1/2 in our study, was previously found to induce invasion, migration, and the angiogenesis of hepatocellular carcinoma cells Huh7 via rapid non-genomic aryl hydrocarbon receptor/G-protein dependent mechanism [70].

In our study, the alterations of rapid signaling events were observed in WB-F344 cells, which have characteristics of liver oval cells or LSPCs. These types of cells are activated during various liver (toxico-)pathologies, and their activation correlates with the levels of tissue damage and inflammation [21,26]; therefore, they are crucial for liver healing and regeneration. Specifically, WB-F344 cells are non-tumorigenic GJIC-communicating rat liver oval cells that have been shown to undergo in vitro transformation into malignant/tumorigenic and GJIC-deficient cells in response to oncogene overexpression [71], mutagenization [72] as well as chemical exposures [73,74].

Our findings indicate the importance of studying the effects of chemicals on GJIC and rapid signaling mechanisms not only in differentiated hepatocytes, where the major building block of gap junctions is connexin 32 [29,34,58] but also in liver oval cells and LSPCs, such as WB-F344, which predominantly express connexin 43 [27]. Connexin 43 is the most abundant and studied connexin type, whose activity and function can be regulated by the direct phosphorylation caused by many kinases, including MAPK-Erk-1/2 [39,41,75]. While the activation of MAPK kinases is considered to be one of the mechanisms of GJIC dysregulation $[41,76,77]$, it has been reported that various environmental toxicants and endocrine disrupters can dysregulate GJIC via mechanisms independent from the MAPK-Erk1/2 pathway, even when MAPK-Erk1/2 activation is associated with 
GJIC dysregulation [41,43-45]. Although GJIC-inhibiting phthalates also activated the MAPK-Erk1/2 pathways in our study, the rapid MAPK-Erk1/2 activation caused by phthalates from Groups E and F was not necessarily associated with the rapid inhibition of GJIC. It suggests that other mechanisms and pathways, independent or co-dependent on pErk1/2, were probably also involved in the rapid dysregulation of GJIC in response to phthalates. The upstream regulators of GJIC and Erk1/2 targeted by phthalates in connexin 43-expressing liver oval cells and the exact signal transduction mechanisms leading to GJIC inhibition thus need to be elucidated in future studies.

The effective concentrations of the most potent phthalates from Group C were $\sim 4-25 \mathrm{mg} / \mathrm{L}$, which are concentrations very close to the concentrations measured in the human biomonitoring of phthalates and their mixtures. The monitoring is predominantly based on the detection of phthalate metabolites in urine, which represents the main route of phthalate elimination. However, phthalates and their metabolites can also be detected in other body fluids, including blood (plasma and serum), amniotic fluid, breast milk, saliva, or seminal fluid [78]. The concentrations of selected phthalate diesters (DEP, DBP, BBP, DEHP) in human blood plasma or serum can be often found in the range of 0.001-0.5 mg/L [79-84], with even higher mean values $(0.2-4.4 \mathrm{mg} / \mathrm{L})$ reported for specific populations, such as Asian women in advanced stages of endometriosis [82-84].

\section{Materials and Methods}

\subsection{Chemicals}

All ingredients for phosphate-buffered saline (PBS, $10 \mathrm{mM}, \mathrm{pH}$ 7.4), formaldehyde, methanol, phthalates (purity: $>97 \%$ ), lucifer yellow dye dilithium salt, 12-O-tetradecanoylphorbol 13-acetate (TPA) and neutral red solution were obtained from Sigma-Aldrich (St. Louis, MO, USA). Additionally, 5-carboxyfluorescein diacetate-acetoxymethyl ester (CFDA-AM) and Alamar Blue ${ }^{\circledR}$ solution were purchased from Thermo Fisher Scientific (Waltham, MA, USA).

\subsection{Cell Culture and Experimental Set-up}

Rat liver epithelial cells WB-F344 [47] were kindly provided by Prof. Trosko and Dr. Upham (Michigan State University, the College of Human Medicine, Department of Pediatrics and Human Development, MI, USA). The cells were cultured in DMEM media (Thermo, Cat. No. 11880) supplemented with $2 \mathrm{mM}$ glutamine (GE Healthcare, Chicago, IL, USA) and 5\% fetal bovine serum (Biosera, Nuaille, France), grown in $25 \mathrm{~cm}^{2}$ tissue culture flasks (TPP, Trasadingen, Switzerland) at $37{ }^{\circ} \mathrm{C}$ in a humidified atmosphere containing $5 \% \mathrm{CO}_{2}$ and passaged $2-3 \times$ per week. Before each experiment, the WB-F344 cells were seeded $\left(40 \times 10^{3}\right.$ or $20 \times 10^{3}$ cells $\left./ \mathrm{cm}^{2}\right)$ in a 96 -well microplate (TPP; cell viability assay) or a $35 \mathrm{~mm}$-dish (TPP; GJIC assay and Western blot) and cultured for $48 \mathrm{~h}$ (cell seeding density: $40 \times 10^{3} \mathrm{~cm}^{2}$ ) or $72 \mathrm{~h}$ (cell seeding density: $20 \times 10^{3} \mathrm{~cm}^{2}$ ) to reach $100 \%$ confluence. Phthalates were dissolved in acetonitrile and TPA in ethanol. Each dissolved compound was added directly to the culture media. Vehicle concentration did not exceed $1 \%(v / v)$ in any experiment, and the corresponding vehicle or negative (non-treated) controls were conducted in each experiment.

\subsection{Cell Viability Assay}

After $24 \mathrm{~h}$ treatment, the exposed cells were rinsed with PBS (pH 7.2) and incubated in serum-free culture media containing 5\% v/v Alamar Blue ${ }^{\circledR}$ and $4 \mu \mathrm{M}$ CFDA-AM. After a 30 min incubation, the fluorescence was measured using microplate reader Synergy 4 Reader (BioTek, Winooski, VT, USA) at 485/520 nm excitation/emission for CFDA and 530/590 nm excitation/emission for Alamar Blue ${ }^{\circledR}$. The cells were then rinsed with PBS and incubated for $2 \mathrm{~h}$ with $50 \mu \mathrm{g} / \mathrm{mL}$ of neutral red dissolved in serum-free culture media and washed again with PBS. Accumulated neutral red was extracted with $50 \%(v / v)$ ethanol-1\% $(v / v)$ acetic acid and quantified spectrophotometrically (Synergy 4$)$ at $540 \mathrm{~nm}$ with $690 \mathrm{~nm}$ reference wavelength. Fluorescence and absorbance readings from the assay blank wells without cells were subtracted from the experimental wells before data analysis. 


\subsection{GJIC Assay}

GJIC was evaluated by the scalpel load/dye transfer (SL/DT) technique adapted after the method of [85] and modified according to the recent protocols [42,86]. The exposed cells were rinsed with PBS supplemented with calcium and magnesium (CaMgPBS; pH 7.2). Fluorescent dye lucifer yellow $(1 \mathrm{mg} / \mathrm{mL}$, dissolved in CaMgPBS) was added to the cells, and three parallel cuts with a surgical scalpel blade were done per dish to introduce the dye into the cell monolayer. After 3 min of incubation to allow the diffusion of lucifer yellow across the monolayer through functional GJ, the cells were rinsed with CaMgPBS and fixated with a $4 \%(v / v)$ formaldehyde solution in PBS. Dye-transfer, which is proportional to GIIC, was documented by fluorescence microscope Axio Observer.Z1 equipped with a 10× objective, AxioCam HRc camera, Filter Set 05 (AF 430 channel: excitation-390-440 nm, emission: 470 LP) and AxioVision software (Carl Zeiss Microscopy, Jena, Germany). A representative image was taken from each cut, and dye transfer was evaluated as an area of lucifer yellow-stained cells along with each cut by ImageJ [87]. The fluorescence area from the positive control treated with a model GJIC dysregulator, TPA [77], at a dose that induced the complete inhibition of GJIC, was subtracted from each treatment to calculate the net dye-transfer area. In addition, the exposed cells were evaluated by brightfield microscopy for signs of cell detachment, disruptions of $100 \%$ confluency and of the integrity of cell monolayer, which can affect the results of GJIC assay.

\subsection{Western Blot}

Western blot was done according to [88]. Briefly, after $0.5 \mathrm{~h}$ exposure, the cells were rinsed with PBS and lysed with $4 \%(w / v)$ sodium dodecyl sulfate (SDS) in $20 \mathrm{mM}$ Tris-HCl with $1 \mathrm{mM}$ dithiothreitol. Total proteins were quantified by the DC Protein Assay (Bio-Rad, Hercules, CA, USA). Proteins (10 $\mu \mathrm{g}$ per sample) were separated using SDS-PAGE on 10\% gel, followed by Western transfer to Immobilon-P membrane (Millipore, Darmstadt, Germany). Immunodetection was conducted by following primary antibodies: 1:1000 diluted rabbit anti-p44/42 (Cell Signaling, Danvers, MA, USA; \#4695S) to detect total Erk1/2 and anti-phospho-p44/42 (Cell Signaling; \#4370S) to detect phosphorylated (activated) Erk1/2, and mouse antibody anti-GAPDH (anti-glyceraldehyde-3-phosphate dehydrogenase; Millipore, \#MAB374) to detect a reference protein. After washing the membranes, 1:2500 diluted anti-rabbit (Cell Signaling, \#7074S) or anti-mouse (Cell Signaling, \#7076S) antibodies labeled with horseradish peroxidase were used to detect primary antibodies. Immunoblots were developed using Clarity ECL Western Blotting Substrate (Bio-Rad) and chemiluminescence documented by the gel imaging system MF-Chemibis (DNR Bio-Imaging Systems, Neve Yamin, Israel). Band densities were determined by Image [87], and the density of the activated (phosphorylated) Erk1/2 bands was normalized to the density of the total Erk1/2 band. TPA at the concentration of $10 \mathrm{nM}$ was used as a model activator of a MAPK-Erk1/2 pathway [77].

\subsection{Reverse Transcription-Polymerase Chain Reaction (RT-PCR)}

RT-PCR was done according to [88]. RNeasy Plus Mini (QIAGEN, Hilden, Germany) was used to isolate the total RNA from the cells. Transcriptor First Strand cDNA Synthesis Kit (Roche, Basel, Switzerland) was used to prepare the cDNA, and Phusion High-Fidelity DNA Polymerase kit (ThermoFisher) to conduct PCR. The primers (Table S3) were designed by Primer3 (version 4.1.0) [89] to bind on an exon-intron border or different exons to minimize the inaccuracies due to possible genomic contamination, to recognize all known transcript variants of a target gene and to avoid pseudogene counterparts. Primary lysates from adult rat liver were kindly provided by the Department of Pathological Physiology (Masaryk University, Brno, Czech Republic). They were used as positive controls to detect mRNA of Ppars.

\subsection{Data and Statistical Analyses}

Appropriate vehicle control was included in all experiments, and vehicle treatments did not significantly differ from the non-treated cells (negative control). All quantitative data (GJIC assay, cell 
viability assay, Western blot densitometry) were normalized to the negative or vehicle controls from the corresponding experiment and reported as the percentage of the control (negative control $=100 \%$ ), or fraction of the control $(F O C$, negative control $=1)$. Control-normalized data from at least three-times independently repeated experiments were combined for all statistical analyses and data presentation. Curve-fitting was done using a non-linear, 4-parameter sigmoidal regression model using GraphPad Prism 5 (GraphPad Software, La Jolla, CA, USA). Statistical analysis was done using SigmaPlot 12.1 (Systat Software GmbH, Erkrath, Germany). Data passing normality (Shapiro-Wilk's test) and equal variance tests were compared by $t$-test or by one-way ANOVA followed by Dunnett's test. Data with unequal variances or non-normal distribution were evaluated by the Mann-Whitney $U$ test, or by the Kruskal-Wallis ANOVA on ranks followed by Dunn's test. $p$-values lower than 0.05 were considered as statistically significant.

\section{Conclusions}

Altogether, toxicologically relevant concentrations of phthalate diesters with medium length side chains elicited rapid and likely Ppar $\alpha$-independent signaling events in rat liver oval WB-F344 cells. This type of liver cells is increasingly recognized for its role in tissue homeostasis, chronic toxicities, and diseases, including hepatocellular carcinomas $[17,19,21]$. While liver-toxic and hepatocarcinogenic effects of phthalates are continuously discussed [65], most studies are focused on genomic signaling as the principal mechanism, and considering hepatocytes or hepatoma cell lines as the target cell populations involved in phthalate tumor-promoting and liver-toxic effects (Table S2). However, our results suggest that phthalates can also act via non-genomic mechanisms in liver oval cells or LSPCs. The GJIC and MAPK-Erk1/2 signaling pathway represent key mechanisms involved in the maintenance of liver tissue homeostasis, whose disruption in the critical population of liver oval cells might be contributing to phthalate-induced hepatotoxicities and the possible development of chronic liver diseases such as liver cancer. These mechanisms and cellular models should be further addressed by future studies to improve phthalate hazard and risk assessment concerning the ongoing occurrence of phthalates in everyday life. GJIC represents an interesting cellular endpoint, which can be nowadays assessed in vitro in a (semi)high-throughput set-ups, and thus can be utilized for the non-genotoxic carcinogens assessment, chemical hazard identification as well as mechanistic studies $[48,90,91]$.

Supplementary Materials: Supplementary materials can be found at http://www.mdpi.com/1422-0067/21/17/ 6069/s1.

Author Contributions: Conceptualization, L.Č., P.B. and I.S.; formal analysis, L.Č., D.J., J.R. and I.S.; funding acquisition, and I.S.; investigation, L.Č., D.J. and J.R.; methodology, L.Č., D.J., J.R. and I.S.; project administration, P.B. and I.S.; resources, P.B. and I.S.; supervision, P.B. and I.S.; visualization, L.Č., I.S.; writing-original draft, L.Č. and I.S.; writing-review and editing, L.Č., D.J., J.R., P.B. and I.S. All authors have read and agreed to the published version of the manuscript.

Funding: This research was funded by the Czech Science Foundation (grant No. GJ16-10775Y), RECETOX Research Infrastructure (LM2018121), CETOCOEN EXCELLENCE Teaming 2 project supported by Horizon2020 (857560) and the Czech Ministry of Education (02.1.01/0.0/0.0/18_046/0015975), and by the long-term research development project of Institute of Botany (RVO 67985939). The Brno Ph.D. Talent programme provided a scholarship for the doctoral study of Jan Raška.

Acknowledgments: We would like to thank Zuzana Klímová for the technical assistance with the experiments.

Conflicts of Interest: The authors declare no conflict of interest. The funders had no role in the design of the study; in the collection, analyses, or interpretation of data; in the writing of the manuscript, or in the decision to publish the results. 


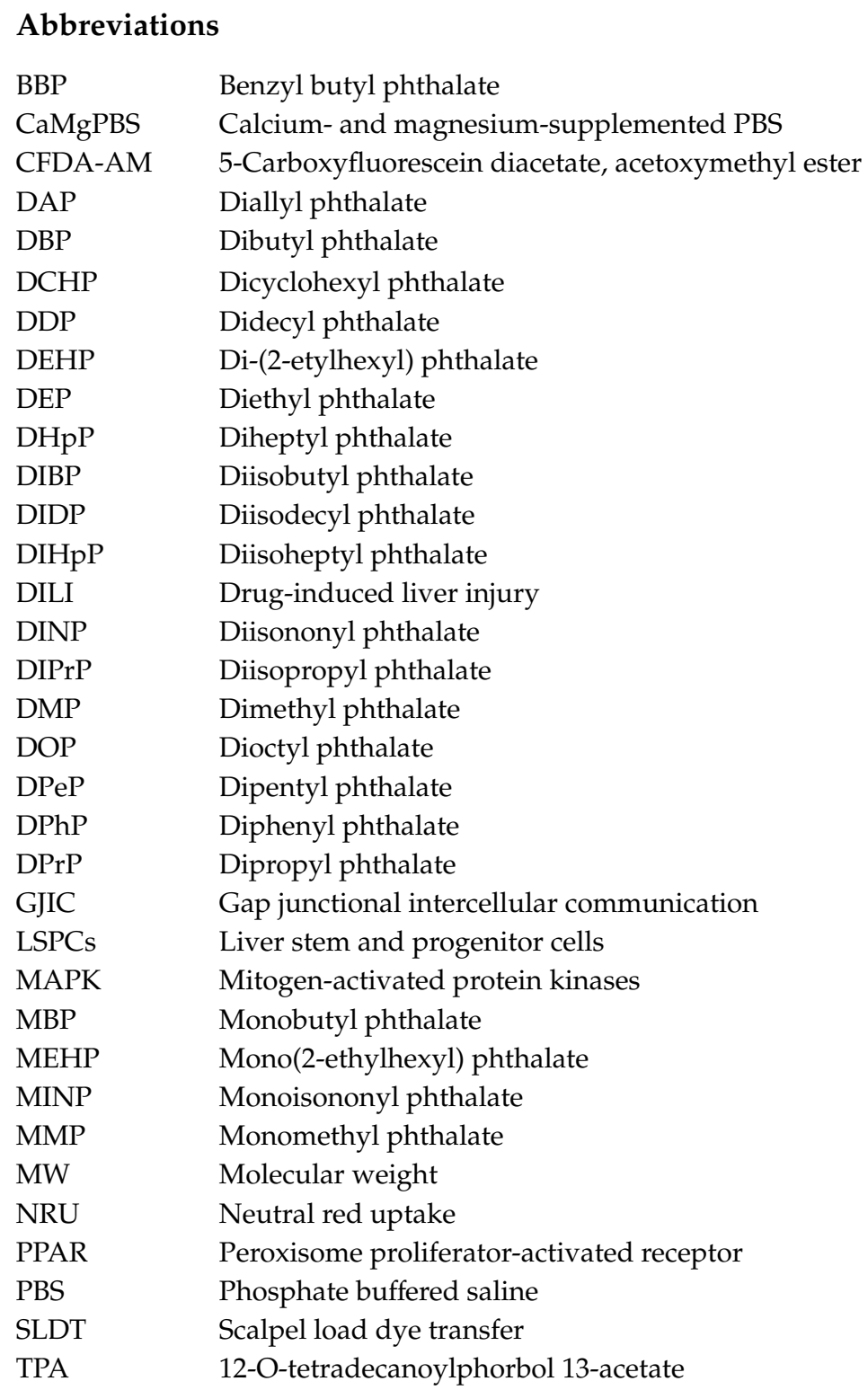

\section{References}

1. Schettler, T. Human exposure to phthalates via consumer products. Int. J. 2006, 29, 134-135. [CrossRef] [PubMed]

2. Horn, O.; Nalli, S.; Cooper, D.; Nicell, J. Plasticizer metabolites in the environment. Water Res. 2004, 38, 3693-3698. [CrossRef]

3. Przybylińska, P.A.; Wyszkowski, M. Environmental contamination with phthalates and its impact on living organisms. Ecol. Chem. Eng. S 2016, 23, 347-356. [CrossRef]

4. Huang, P.C.; Tien, C.J.; Sun, Y.M.; Hsieh, C.Y.; Lee, C.C. Occurrence of phthalates in sediment and biota: Relationship to aquatic factors and the biota-sediment accumulation factor. Chemosphere 2008, 73, 539-544. [CrossRef] [PubMed]

5. Rowdhwal, S.S.S.; Chen, J. Toxic effects of di-2-ethylhexyl phthalate: An overview. Biomed Res. Int. 2018, 2018, 1750368. [CrossRef] [PubMed]

6. Heudorf, U.; Mersch-Sundermann, V.; Angerer, J. Phthalates: Toxicology and exposure. Int. J. Hyg. Environ. Health 2007, 210, 623-634. [CrossRef]

7. Ashworth, M.J.; Chappell, A.; Ashmore, E.; Fowles, J. Analysis and assessment of exposure to selected phthalates found in children's toys in Christchurch, New Zealand. Int. J. Environ. Res. Public Health 2018, 15, 200. [CrossRef] 
8. Larsson, K.; Lindh, C.H.; Jonsson, B.A.; Giovanoulis, G.; Bibi, M.; Bottai, M.; Bergstrom, A.; Berglund, M. Phthalates, non-phthalate plasticizers and bisphenols in Swedish preschool dust in relation to children's exposure. Environ. Int. 2017, 102, 114-124. [CrossRef]

9. Latini, G. Monitoring phthalate exposure in humans. Clin. Chim. Acta 2005, 361, 20-29. [CrossRef] 
10. Ito, Y.; Yamanoshita, O.; Asaeda, N.; Tagawa, Y.; Lee, C.-H.; Aoyama, T.; Ichihara, G.; Furuhashi, K.; Kamijima, M.; Gonzalez, F.J.; et al. Di(2-ethylhexyl)phthalate induces hepatic tumorigenesis through a peroxisome proliferator-activated receptor alpha-independent pathway. J. Occup. Health 2007, 49, 172-182. [CrossRef]

11. Wang, Y.-C.; Chen, H.-S.; Long, C.-Y.; Tsai, C.-F.; Hsieh, T.-H.; Hsu, C.-Y.; Tsai, E.-M. Possible mechanism of phthalates-induced tumorigenesis. Kaohsiung J. Med. Sci. 2012, 28, S22-S27. [CrossRef] [PubMed]

12. Butterworth, B.E.; Bermudez, E.; Smith-Oliver, T.; Earle, L.; Cattley, R.; Martin, J.; Popp, J.A.; Strom, S.; Jirtle, R.; Michalopoulos, G. Lack of genotoxic activity of di(2-ethylhexyl)phthalate (DEHP) in rat and human hepatocytes | Carcinogenesis | Oxford Academic. Carcinogenesis 1984, 5, 1329-1335. [CrossRef]

13. Benjamin, S.; Masai, E.; Kamimura, N.; Takahashi, K.; Anderson, R.C.; Faisal, P.A. Phthalates impact human health: Epidemiological evidences and plausible mechanism of action. J. Hazard. Mater. 2017, 340, 360-383. [CrossRef] [PubMed]

14. Miao, Y.; Wang, R.; Lu, C.; Zhao, J.; Deng, Q. Lifetime cancer risk assessment for inhalation exposure to di(2-ethylhexyl) phthalate (DEHP). Environ. Sci. Pollut. Res. Int. 2017, 24, 312-320. [CrossRef]

15. United States Environmental Protection Agency. Integrated Risk Information System: Di(2-ethylhexyl) Phthalate (DEHP) (CASRN 117-81-7). Available online: https://cfpub.epa.gov/ncea/iris/iris_documents/ documents/subst/0014_summary.pdf (accessed on 22 August 2020).

16. Berardis, S.; Sokal, E. Pediatric non-alcoholic fatty liver disease: An increasing public health issue. Eur. J. Pediatr. 2014, 173, 131-139. [CrossRef] [PubMed]

17. Fausto, N.; Campbell, J.S. The role of hepatocytes and oval cells in liver regeneration and repopulation. Mech. Dev. 2003, 120, 117-130. [CrossRef]

18. Huch, M.; Dorrell, C.; Boj, S.F.; van Es, J.H.; Li, V.S.W.; van de Wetering, M.; Sato, T.; Hamer, K.; Sasaki, N.; Finegold, M.J.; et al. In vitro expansion of single Lgr5+ liver stem cells induced by Wnt-driven regeneration. Nature 2013, 494, 247-250. [CrossRef]

19. Kholodenko, I.V.; Yarygin, K.N. Cellular mechanisms of liver regeneration and cell-based therapies of liver diseases. Biomed Res. Int. 2017, 2017, 8910821. [CrossRef]

20. Sadri, A.-R.; Jeschke, M.G.; Amini-Nik, S. Advances in liver regeneration: Revisiting hepatic stem/progenitor cells and their origin. Stem Cells Int. 2016, 2016, 7920897. [CrossRef]

21. Canovas-Jorda, D.; Louisse, J.; Pistollato, F.; Zagoura, D.; Bremer, S. Regenerative toxicology: The role of stem cells in the development of chronic toxicities. Expert Opin. Drug Metab. Toxicol. 2014, 10, 39-50. [CrossRef]

22. Kang, K.-S.; Trosko, J.E. Stem cells in toxicology: Fundamental biology and practical considerations. Toxicol. Sci. 2011, 120, S269-S289. [CrossRef] [PubMed]

23. Knight, B.; Lim, R.; Yeoh, G.C.; Olynyk, J.K. Interferon-gamma exacerbates liver damage, the hepatic progenitor cell response and fibrosis in a mouse model of chronic liver injury. J. Hepatol. 2007, 47, 826-833. [CrossRef]

24. Persano, L.; Zagoura, D.; Louisse, J.; Pistollato, F. Role of environmental chemicals, processed food derivatives, and nutrients in the induction of carcinogenesis. Stem Cells Dev. 2015, 24, 2337-2352. [CrossRef]

25. Vanova, T.; Raska, J.; Babica, P.; Sovadinova, I.; Kunova Bosakova, M.; Dvorak, P.; Blaha, L.; Rotrekl, V. Freshwater Cyanotoxin Cylindrospermopsin Has Detrimental Stage-specific Effects on hepatic differentiation from human embryonic stem cells. Toxicol. Sci. 2019, 168, 241-251. [CrossRef] [PubMed]

26. Wang, K.; Sun, D. Cancer stem cells of hepatocellular carcinoma. Oncotarget 2018, 9, 23306-23314. [CrossRef] [PubMed]

27. Vondráček, J.; Machala, M.; Vondracek, J.; Machala, M.; Vondráček, J.; Machala, M. Environmental ligands of the aryl hydrocarbon receptor and their effects in models of adult liver progenitor cells. Stem Cells Int. 2016, 2016, 4326194. [CrossRef]

28. Hernández-Guerra, M.; Hadjihambi, A.; Jalan, R. Gap junctions in liver disease: Implications for pathogenesis and therapy. J. Hepatol. 2019, 70, 759-772. [CrossRef]

29. Maes, M.; Vinken, M. Connexin-based signaling and drug-induced hepatotoxicity. J. Clin. Transl. Res. 2017, 3, 189-198. [CrossRef]

30. Aasen, T.; Mesnil, M.; Naus, C.C.; Lampe, P.D.; Laird, D.W. Gap junctions and cancer: Communicating for 50 years. Nat. Rev. Cancer 2016, 16, 775-788. [CrossRef] 
31. Sai, K.; Upham, B.L.; Kang, K.S.; Hasegawa, R.; Inoue, T.; Trosko, J.E. Inhibitory effect of pentachlorophenol on gap junctional intercellular communication in rat liver epithelial cells in vitro. Cancer Lett. 1998, 130, 9-17. [CrossRef]

32. Trosko, J.E.; Ruch, R.J. Cell-cell communication in carcinogenesis. Front. Biosci. 1998, 3, d208-d236. [CrossRef] [PubMed]

33. Trosko, J.E.; Ruch, R.J. Gap junctions as targets for cancer chemoprevention and chemotherapy. Curr. Drug Targets 2002, 3, 465-482. [CrossRef] [PubMed]

34. Vinken, M. Gap junctions and non-neoplastic liver disease. J. Hepatol. 2012, 57, 655-662. [CrossRef] [PubMed]

35. Vinken, M.; Doktorova, T.; Decrock, E.; Leybaert, L.; Vanhaecke, T.; Rogiers, V. Gap junctional intercellular communication as a target for liver toxicity and carcinogenicity. Crit. Rev. Biochem. Mol. Biol. 2009, 44, $201-222$. [CrossRef] [PubMed]

36. Yamasaki, H.; Omori, Y.; Zaidan-Dagli, M.L.; Mironov, N.; Mesnil, M.; Krutovskikh, V. Genetic and epigenetic changes of intercellular communication genes during multistage carcinogenesis. Cancer Detect. Prev. 1999, 23, 273-279. [CrossRef]

37. Jacobs, M.N.; Colacci, A.; Corvi, R.; Vaccari, M.; Aguila, M.C.; Corvaro, M.; Delrue, N.; Desaulniers, D.; Ertych, N.; Jacobs, A.; et al. Chemical carcinogen safety testing: OECD expert group international consensus on the development of an integrated approach for the testing and assessment of chemical non-genotoxic carcinogens. Arch. Toxicol. 2020, 1, 3. [CrossRef]

38. Hu, W.; Jones, P.D.; Upham, B.L.; Trosko, J.E.; Lau, C.; Giesy, J.P. Inhibition of gap junctional intercellular communication by perfluorinated compounds in rat liver and dolphin kidney epithelial cell lines in vitro and Sprague-Dawley rats in vivo. Toxicol. Sci. 2002, 68, 429-436. [CrossRef]

39. Kubincova, P.; Sychrova, E.; Raska, J.; Basu, A.; Yawer, A.; Dydowiczova, A.; Babica, P.; Sovadinova, I. Polycyclic aromatic hydrocarbons and endocrine disruption: Role of testicular gap junctional intercellular communication and connexins. Toxicol. Sci. 2019, 169, 70-83. [CrossRef]

40. Osgood, R.S.; Upham, B.L.; Hill, T., 3rd; Helms, K.L.; Velmurugan, K.; Babica, P.; Bauer, A.K. Polycyclic aromatic hydrocarbon-induced signaling events relevant to inflammation and tumorigenesis in lung cells are dependent on molecular structure. PLoS ONE 2014, 8, e65150. [CrossRef]

41. Sovadinova, I.; Babica, P.; Boke, H.; Kumar, E.; Wilke, A.; Park, J.-S.; Trosko, J.E.; Upham, B.L. Phosphatidylcholine specific PLC-induced dysregulation of gap junctions, a robust cellular response to environmental toxicants, and prevention by resveratrol in a rat liver cell model. PLoS ONE 2015, 10, e0124454. [CrossRef]

42. Upham, B.L.; Sovadinova, I.; Babica, P.; Sovadinová, I.; Babica, P. Gap junctional intercellular communication: A functional biomarker to assess adverse effects of toxicants and toxins, and health benefits of natural products. J. Vis. Exp. 2016, 2016. [CrossRef] [PubMed]

43. Upham, B.L.; Park, J.-S.; Babica, P.; Sovadinova, I.; Rummel, A.M.; Trosko, J.E.; Hirose, A.; Hasegawa, R.; Kanno, J.; Sai, K. Structure-activity-dependent regulation of cell communication by perfluorinated fatty acids using in vivo and in vitro model systems. Environ. Health Perspect. 2009, 117, 545-551. [CrossRef] [PubMed]

44. Upham, B.L.; Blaha, L.; Babica, P.; Park, J.-S.; Sovadinova, I.; Pudrith, C.; Rummel, A.M.; Weis, L.M.; Sai, K.; Tithof, P.K.; et al. Tumor promoting properties of a cigarette smoke prevalent polycyclic aromatic hydrocarbon as indicated by the inhibition of gap junctional intercellular communication via phosphatidylcholine-specific phospholipase C. Cancer Sci. 2008, 99, 696-705. [CrossRef] [PubMed]

45. Babica, P.; Zurabian, R.; Kumar, E.R.; Chopra, R.; Mianecki, M.J.; Park, J.-S.; Jasa, L.; Trosko, J.E.; Upham, B.L. Methoxychlor and vinclozolin induce rapid changes in intercellular and intracellular signaling in liver progenitor cells. Toxicol. Sci. 2016, 153, 174-185. [CrossRef]

46. Klaunig, J.E.; Ruch, R.J.; DeAngelo, A.B.; Kaylor, W.H. Inhibition of mouse hepatocyte intercellular communication by phthalate monoesters. Cancer Lett. 1988, 43, 65-71. [CrossRef]

47. Tsao, M.S.; Smith, J.D.; Nelson, K.G.; Grisham, J.W. A diploid epithelial cell line from normal adult rat liver with phenotypic properties of "oval" cells. Exp. Cell Res. 1984, 154, 38-52. [CrossRef]

48. Dydowiczová, A.; Brózman, O.; Babica, P.; Sovadinová, I.; Dydowiczova, A.; Brozman, O.; Babica, P.; Sovadinova, I. Improved multiparametric scrape loading-dye transfer assay for a simultaneous high-throughput analysis of gap junctional intercellular communication, cell density and viability. Sci. Rep. 2020, 10, 730. [CrossRef] 
49. Lawan, A.; Bennett, A.M. Mitogen-Activated Protein Kinase Regulation in Hepatic Metabolism. Trends Endocrinol. Metab. 2017, 28, 868-878. [CrossRef]

50. McMullen, P.D.; Bhattacharya, S.; Woods, C.G.; Pendse, S.N.; McBride, M.T.; Soldatow, V.Y.; Deisenroth, C.; LeCluyse, E.L.; Clewell, R.A.; Andersen, M.E. Identifying qualitative differences in PPAR $\alpha$ signaling networks in human and rat hepatocytes and their significance for next generation chemical risk assessment methods. Toxicol. In Vitro 2020, 64, 104463. [CrossRef]

51. Mathieu-Denoncourt, J.; Wallace, S.J.; de Solla, S.R.; Langlois, V.S. Plasticizer endocrine disruption: Highlighting developmental and reproductive effects in mammals and non-mammalian aquatic species. Gen. Comp. Endocrinol. 2015, 219, 74-88. [CrossRef]

52. Ambe, K.; Sakakibara, Y.; Sakabe, A.; Makino, H.; Ochibe, T.; Tohkin, M. Comparison of the developmental/ reproductive toxicity and hepatotoxicity of phthalate esters in rats using an open toxicity data source. J. Toxicol. Sci. 2019, 44, 245-255. [CrossRef] [PubMed]

53. Han, H.; Lee, H.A.; Park, B.; Park, B.; Hong, Y.S.; Ha, E.H.; Park, H. Associations of phthalate exposure with lipid levels and insulin sensitivity index in children: A prospective cohort study. Sci. Total Environ. 2019, 662, 714-721. [CrossRef] [PubMed]

54. Milosevic, N.; Milic, N.; Zivanovic Bosic, D.; Bajkin, I.; Percic, I.; Abenavoli, L.; Medic Stojanoska, M. Potential influence of the phthalates on normal liver function and cardiometabolic risk in males. Environ. Monit. Assess. 2017, 190, 17. [CrossRef]

55. Trasande, L.; Spanier, A.J.; Sathyanarayana, S.; Attina, T.M.; Blustein, J. Urinary phthalates and increased insulin resistance in adolescents. Pediatrics 2013, 132, e646-e655. [CrossRef] [PubMed]

56. Praveena, S.M.; Teh, S.W.; Rajendran, R.K.; Kannan, N.; Lin, C.-C.; Abdullah, R.; Kumar, S. Recent updates on phthalate exposure and human health: A special focus on liver toxicity and stem cell regeneration. Environ. Sci. Pollut. Res. Int. 2018, 25, 11333-11342. [CrossRef]

57. Rusyn, I.; Peters, J.M.; Cunningham, M.L. Modes of action and species-specific effects of di-(2-ethylhexyl)phthalate in the liver. Crit. Rev. Toxicol. 2006, 36, 459-479. [CrossRef]

58. Maes, M.; Yanguas, S.C.; Willebrords, J.; Vinken, M. Models and methods for in vitro testing of hepatic gap junctional communication. Toxicol. Vitr. 2015, 30, 569-577. [CrossRef]

59. Smith, J.H.; Isenberg, J.S.; Pugh, G.J.; Kamendulis, L.M.; Ackley, D.; Lington, A.W.; Klaunig, J.E. Comparative in vivo hepatic effects of Di-isononyl phthalate (DINP) and related C7-C11 dialkyl phthalates on gap junctional intercellular communication (GJIC), peroxisomal beta-oxidation (PBOX), and DNA synthesis in rat and mouse liver. Toxicol. Sci. 2000, 54, 312-321. [CrossRef]

60. Pugh, G.J.; Isenberg, J.S.; Kamendulis, L.M.; Ackley, D.C.; Clare, L.J.; Brown, R.; Lington, A.W.; Smith, J.H.; Klaunig, J.E. Effects of di-isononyl phthalate, di-2-ethylhexyl phthalate, and clofibrate in cynomolgus monkeys. Toxicol. Sci. 2000, 56, 181-188. [CrossRef]

61. Isenberg, J.S.; Kamendulis, L.M.; Smith, J.H.; Ackley, D.C.; Pugh, G.J.; Lington, A.W.; Klaunig, J.E. Effects of Di-2-ethylhexyl phthalate (DEHP) on gap-junctional intercellular communication (GJIC), DNA synthesis, and peroxisomal beta oxidation (PBOX) in rat, mouse, and hamster liver. Toxicol. Sci. 2000, 56, 73-85. [CrossRef]

62. McKee, R.H. The role of inhibition of gap junctional intercellular communication in rodent liver tumor induction by phthalates: Review of data on selected phthalates and the potential relevance to man. Regul. Toxicol. Pharm. 2000, 32, 51-55. [CrossRef] [PubMed]

63. Melnick, R.L. Is peroxisome proliferation an obligatory precursor step in the carcinogenicity of di(2-ethylhexyl)phthalate (DEHP)? Environ. Health Perspect. 2001, 109, 437-442. [CrossRef] [PubMed]

64. Kamendulis, L.M.; Isenberg, J.S.; Smith, J.H.; Pugh, G.J.; Lington, A.W.; Klaunig, J.E. Comparative effects of phthalate monoesters on gap junctional intercellular communication and peroxisome proliferation in rodent and primate hepatocytes. J. Toxicol. Environ. Health. A 2002, 65, 569-588. [CrossRef] [PubMed]

65. Pham, N.; Iyer, S.; Hackett, E.; Lock, B.H.; Sandy, M.; Zeise, L.; Solomon, G.; Marty, M. Using ToxCast to explore chemical activities and hazard traits: A case study with ortho-phthalates. Toxicol. Sci. 2016, 151, 286-301. [CrossRef] [PubMed]

66. Corton, J.C.; Peters, J.M.; Klaunig, J.E. The PPAR $\alpha$-dependent rodent liver tumor response is not relevant to humans: Addressing misconceptions. Arch. Toxicol. 2018, 92, 83-119. [CrossRef] 
67. Guyton, K.Z.; Chiu, W.A.; Bateson, T.F.; Jinot, J.; Scott, C.S.; Brown, R.C.; Caldwell, J.C. A reexamination of the PPAR-alpha activation mode of action as a basis for assessing human cancer risks of environmental contaminants. Environ. Health Perspect. 2009, 117, 1664-1672. [CrossRef]

68. Rusyn, I.; Corton, J.C. Mechanistic considerations for human relevance of cancer hazard of di(2-ethylhexyl) phthalate. Mutat. Res. 2012, 750, 141-158. [CrossRef]

69. Li, L.; Zhao, G.-D.; Shi, Z.; Qi, L.-L.; Zhou, L.-Y.; Fu, Z.-X. The Ras/Raf/MEK/ERK signaling pathway and its role in the occurrence and development of HCC. Oncol. Lett. 2016, 12, 3045-3050. [CrossRef]

70. Tsai, C.-F.; Hsieh, T.-H.; Lee, J.-N.; Hsu, C.-Y.; Wang, Y.-C.; Lai, F.-J.; Kuo, K.-K.; Wu, H.-L.; Tsai, E.-M.; Kuo, P.-L. Benzyl butyl phthalate induces migration, invasion, and angiogenesis of Huh7 hepatocellular carcinoma cells through nongenomic AhR/G-protein signaling. BMC Cancer 2014, 14, 556. [CrossRef]

71. Hayashi, T.; Nomata, K.; Chang, C.C.; Ruch, R.J.; Trosko, J.E. Cooperative effects of v-myc and c-Ha-ras oncogenes on gap junctional intercellular communication and tumorigenicity in rat liver epithelial cells. Cancer Lett. 1998, 128, 145-154. [CrossRef]

72. Rae, R.S.; Mehta, P.P.; Chang, C.C.; Trosko, J.E.; Ruch, R.J. Neoplastic phenotype of gap-junctional intercellular communication-deficient WB rat liver epithelial cells and its reversal by forced expression of connexin 32. Mol. Carcinog. 1998, 22, 120-127. [CrossRef]

73. Sun, H.; Liu, G. Chemopreventive effect of dimethyl dicarboxylate biphenyl on malignant transformation of WB-F344 rat liver epithelial cells. Acta Pharm. Sin. 2005, 26, 1339-1344. [CrossRef] [PubMed]

74. Li, X.; Li, Y.; Kang, X.; Guo, K.; Li, H.; Gao, D.; Sun, L.; Liu, Y. Dynamic alteration of protein expression profiles during neoplastic transformation of rat hepatic oval-like cells. Cancer Sci. 2010, 101, 1099-1107. [CrossRef] [PubMed]

75. Solan, J.L.; Lampe, P.D. Connexin43 phosphorylation: Structural changes and biological effects. Biochem. J. 2009, 419, 261-272. [CrossRef]

76. Ruch, R.J.; Trosko, J.E.; Madhukar, B.V. Inhibition of connexin43 gap junctional intercellular communication by TPA requires ERK activation. J. Cell. Biochem. 2001, 83, 163-169. [CrossRef]

77. Rivedal, E.; Opsahl, H. Role of PKC and MAP kinase in EGF- and TPA-induced connexin43 phosphorylation and inhibition of gap junction intercellular communication in rat liver epithelial cells. Carcinogenesis 2001, 22, 1543-1550. [CrossRef]

78. Wang, Y.; Zhu, H.; Kannan, K. A review of biomonitoring of phthalate exposures. Toxics 2019, 7, 21. [CrossRef]

79. Hogberg, J.; Hanberg, A.; Berglund, M.; Skerfving, S.; Remberger, M.; Calafat, A.M.; Filipsson, A.F.; Jansson, B.; Johansson, N.; Appelgren, M.; et al. Phthalate diesters and their metabolites in human breast milk, blood or serum, and urine as biomarkers of exposure in vulnerable populations. Environ. Health Perspect. 2008, 116, 334-339. [CrossRef]

80. Wan, H.T.; Leung, P.Y.; Zhao, Y.G.; Wei, X.; Wong, M.H.; Wong, C.K.C. Blood plasma concentrations of endocrine disrupting chemicals in Hong Kong populations. J. Hazard. Mater. 2013, 261, 763-769. [CrossRef]

81. Chen, J.; Liu, H.; Qiu, Z.; Shu, W. Analysis of di-n-butyl phthalate and other organic pollutants in Chongqing women undergoing parturition. Environ. Pollut. 2008, 156, 849-853. [CrossRef]

82. Kim, S.H.; Chun, S.; Jang, J.Y.; Chae, H.D.; Kim, C.-H.; Kang, B.M. Increased plasma levels of phthalate esters in women with advanced-stage endometriosis: A prospective case-control study. Fertil. Steril. 2011, 95, 357-359. [CrossRef] [PubMed]

83. Reddy, B.S.; Rozati, R.; Reddy, B.V.R.; Raman, N.V.V.S.S. Association of phthalate esters with endometriosis in Indian women. BJOG 2006, 113, 515-520. [CrossRef] [PubMed]

84. Reddy, B.S.; Rozati, R.; Reddy, S.; Kodampur, S.; Reddy, P.; Reddy, R. High plasma concentrations of polychlorinated biphenyls and phthalate esters in women with endometriosis: A prospective case control study. Fertil. Steril. 2006, 85, 775-779. [CrossRef] [PubMed]

85. El-Fouly, M.H.; Trosko, J.E.; Chang, C.-C. Scrape-loading and dye transfer: A rapid and simple technique to study gap junctional intercellular communication. Exp. Cell Res. 1987, 168, 422-430. [CrossRef]

86. Babica, P.; Sovadinová, I.; Upham, B.L. Scrape Loading/Dye Transfer Assay. In Gap Junction Protocols; Vinken, M., Johnstone, S.R., Eds.; Springer: New York, NY, USA, 2016; Volume 1437, pp. 133-144. ISBN 978-1-4939-3664-9.

87. Schneider, C.A.; Rasband, W.S.; Eliceiri, K.W. NIH Image to ImageJ: 25 years of image analysis. Nat. Methods 2012, 9, 671. [CrossRef] 
88. Raska, J.; Ctverackova, L.; Dydowiczova, A.; Sovadinova, I.; Blaha, L.; Babica, P. Tumor-promoting cyanotoxin microcystin-LR does not induce procarcinogenic events in adult human liver stem cells. Toxicol. Appl. Pharm. 2018, 345, 103-113. [CrossRef]

89. Rozen, S.; Skaletsky, H. Primer3 on the WWW for general users and for biologist programmers. Methods Mol. Biol. 2000, 132, 365-386. [CrossRef]

90. Dukic, A.R.; McClymont, D.W.; Tasken, K. A Cell-based high-throughput assay for gap junction communication suitable for assessing connexin 43-Ezrin interaction disruptors using IncuCyte ZOOM. Slas Discov. Adv. Life Sci. R D 2017, 22,77-85. [CrossRef]

91. Picoli, C.; Soleilhac, E.; Journet, A.; Barette, C.; Comte, M.; Giaume, C.; Mouthon, F.; Fauvarque, M.-O.; Charveriat, M. High-content screening identifies new inhibitors of connexin 43 gap junctions. Assay Drug Dev. Technol. 2019, 17, 240-248. [CrossRef]

(C) 2020 by the authors. Licensee MDPI, Basel, Switzerland. This article is an open access article distributed under the terms and conditions of the Creative Commons Attribution (CC BY) license (http://creativecommons.org/licenses/by/4.0/). 